\title{
Financial Services Consolidation and Performance in New York State Savings and Loan Associations, 2000-2011
}

\author{
Mine Aysen Doyran \\ Correspondence: Mine Aysen Doyran, Department of Economics and Business, City University of New York \\ (CUNY)/Lehman College, 250 Bedford Park Blvd. West, Bronx, New York City, NY 10468-1589, USA. Tel: \\ 1-718-960-8297. E-mail: Mine.Doyran@1ehman.cuny.edu
}

Received: January 26, 2012

Accepted: March 8, 2012

Online Published: November 27, 2012

doi:10.5539/ijef.v5n1p8

URL: http://dx.doi.org/10.5539/ijef.v5n1p8

\begin{abstract}
The market structure-performance relationship has been tested for US banking in industrial organization studies. Two divergent hypotheses with regard to this relationship are the Structure-Conduct-Performance (SCP) Paradigm and Efficient Structure Hypothesis (ESH). This paper presents the test results of both hypotheses with respect to the New York State S\&L associations using the time-series and cross sectional (firm-level) data for the most recent period 2000-2010. The results of PEGLS regression indicate that performances of S\&Ls vary with respect to operating cost, credit risk and capitalization. Neither market share nor concentration, however, plays a significant role in explaining profitability. The results partially support the ESH as an explanation for the market behavior of New York State S\&L associatons. Given that profitable banks are efficient but also risk dependent, additional policies are warranted in order to mitigate risk and maintain the safety and soundness for the remaining S\&Ls in the New York State.
\end{abstract}

Keywords: S\&L industry, subprime mortgage crisis, Structure-Conduct-Performance (SCP), Relative Market Power (RMP), Concentration, HHI, Efficient Structure Hypothesis (EFS), X-Efficiency, scale efficiency

JEL: G21; B15; C50; E50; P16

\section{Introduction}

In recent years marked by financial instability, banking sector performance has become an increasingly noteworthy research topic. While this research has been largely limited to US and European banking, a growing body of research examined determinants of performance in non-bank institutions, particularly in the US Savings and Loan associations. For decades, S\&Ls operated as specialized banks offering mortgage loans and savings accounts at low-interest and insured accounts. Studies highlighting firm-specific factors emphasized ownership and control, managerial efficiency and profitable ownership structure. Studies published during the mid-1980s and later extensively focused on regulation, deregulation and insolvency risks and the impact of change in ownership (stock versus mutual) on efficiency and cost structure (Balderston 1985; Benston, 1986; Kane, 1989; Barth, 1991; Curry and Shibut, 2000; Mester, 1993; Cebenoyan, Cooperman and Register, 1995; Fraser and Zardkoohi, 1996).

Since the unfolding of the US financial crisis in 2007, bank performance has received renewed attention in the ongoing effort to mitigate risks and revitalize the financial industry. Mergers and acquisitions have a bearing on S\&L performance against a backdrop of frequent failures. The aim of this article is therefore two-fold: First, it aims to extend the literature by focusing on the S\&L sector in the New York state. Since New York has been the epicenter of economic crisis, it is noteworthy to look at the current trends in the financial sector in that state. The second aim of this paper is to gain an insight into a significant determinant of financial performance mostly associated with market structures, namely concentration and competition. In this regard, two competing hypotheses--Structure-Conduct-Performance (SCP) Paradigm and Efficient Structure Hypothesis (ESH)--are tested against the background of previous literature. US anti-trust policy that evaluates bank mergers is based on the assumption of positive relationship between market structure (overall concentration level) and collusive profits. On the other hand, ESH suggests that market share of individual firms explains the positive relationship between market structure and firm profits (Evanoff and Fortier, 1988:277). It is hoped that testing the assumptions of these theories can provide new insights for anti-trust policy and financial regulation at the state level. 
In determining performance, we use the most popular proxy measured by Return on Assets (ROA) and regress it with bank-specific and industry-specific indicators. We have not included macroeconomic variables given that all institutions operate in the same macroeconomic environment and there is no a priori reason to assume that profitability levels vary with growth rate of GDP. Our findings indicate that profits are negatively related to operating costs (operational costs/total assets), credit risk and liquidity risk. Risk is one of the most important components of profitability as indicated by the negative coefficient sign of credit risk. This reveals that banks with substantial amount of loan loss provisions-to-total assets make riskier loans than banks with less risky loans A key finding is that neither market share nor the standard concentration ratio (HHI), commonly used in bank performance research, has a significant impact on bank profits. While our evidence partially supports the ESH as an explanation of firm-specific efficiency, it does not support either of the theories as an explanation for the market behavior of New York State S\&Ls. An additional robustness check shows that findings are robust and consistent after controlling industry-related variables and inter-correlation in the sample banks.

The remainder of the article is organized as follows. Section 2 provides a brief overview of the main developments in the Savings and Loan Industry as background to the empirical work. In Section 3, we present an overview of the relevant literature on market structures/performance relationship and discuss the strengths and shortcomings of previous studies. Section 4 and Section 5 present the empirical model along with a description of the data and variables used in the study. Section 6 yields the results of the empirical analysis. Section 7 discusses the policy implications of empirical findings. Section 8 presents the conclusion and draws strategic lessons from this study for future researchers.

\section{Historical Background: Consolidation of New York Savings and Loan Industry}

In the early 1990s, the New York S\&L industry (also known as thrifts) went through a major process of expansion and consolidation. Firms are generally fewer and larger today but operate in increasingly concentrated markets. S\&Ls took larger risks as a result of the deregulation in the early 1980s. During this period, a large number of institutions failed due to undercapitalization, managerial inefficiency and engagement in large-scale speculation, especially in real estate and commercial loans. Various explanations put forward for the crisis include lack of adequate supervision, reduced capital ratios, adverse economic conditions and deregulation of asset structure and interest rates (Balderston 1985; Benston, 1986; Kane, 1989; Barth, 1991; Mishkin, 1999; Curry and Shibut, 2000). In addition, stock-owned institutions displayed more risky portfolios than did mutual institutions (Mester, 1993; Cebenoya et al, 1995; Fraser and Zardkoohi, 1996).

Jayaratne and Hall (1996) argue that consolidation among both types of depository institutions (commercial banks and thrifts) increased from 1989 to 1994 in the Federal Reserve Second District's five largest banking markets: Albany, Buffalo, Metro New York-New Jersey, Rochester and Syracuse. Overall, an increase in consolidation came from three fronts: Thrift failures contributed to increased market concentration more than mergers did, especially in Buffalo, Rochester and Syracuse. Prominent New York City institutions, such as Bank of New York, Dime Savings and Chemical Bank, withdrew entirely from the upstate markets. Additionally, the market share of midsized banks increased at the expense of larger institutions. Using local market deposit concentration (HHI Index) as a proxy for competition in retail banking, they show that HHI increased at a faster rate than the national average in four markets, with Albany experiencing 61 percent increase in concentration. Buffalo experienced the largest decline in the number of institutions while Metro New York-New Jersey experienced the smallest reduction but increased merger activity. Despite the process of consolidation, however, the banking markets remained un-concentrated, with HHI of less than 1000 and competition still vibrant. Overall improved efficiency, elimination of weaker banks, better diversified services and the growth of market share in midsized banks undercut assumptions that the New York market is excessively concentrated.

Failures, mergers and acquisitions reflected a trend towards consolidation at the national level as well. Among New York's 493 depository institutions in 1989, 55 (11.2 percent) were "eliminated" by mergers and 52 (10.5 percent) by thrift failures (Jayaratne and Hall, 1996:2). From January 1, 1986 to year-end 1995, "the number of federally insured thrift institutions in the United States declined from 3,234 to 1,645 or by approximately 50 percent" (Curry and Shibut, 2000:26). As some weaker institutions were eliminated, many prominent and large S\&Ls like Washington Mutual and World Savings became subsidiaries of bank holding companies (Ely, 2008). Market consolidation continued unabated with the financial crisis in 2008, when failures such as IndyMac led to the third largest bank collapse in US history, costing "more than $10 \%$ of the FDIC's $\$ 53$ billion deposit insurance fund" after Continental Illinois in 1986 and First Republic Bank in 1988 (Palette and Enrich, 2008). IndyMac speculated in Alt-A loans, one level up from subprime loans (Hudson, 2008). Washington Mutual, the largest American savings and loan association, also collapsed in 2008, ending in the largest bank failure in US history to date and facilitating its acquisition by J.P Morgan Chase for $\$ 1.9$ billion. 
During the 2007-2010 crisis, New York banking experienced some consolidation but the statistics do not confirm decreased competition in local markets. According to Wheelock (2011), the crisis eliminated 318 commercial banks and savings institutions, nearly 4 percent of total number of banks at the end of 2006. For example, the acquisition of Washington Mutual had little effect on competitive conditions in financial centers. Especially Houston and New York City stayed relatively un-concentrated after the acquisition. Except for a few rural banking markets, market concentration did not increase after acquisitions of failed banks by competitors. Banks that acquired some of the failed banks were already serving the same market.

When we examine all New York State S\&L institutions in 2011, the consolidation over the 2000-2011 was in fact modest (Figure 2). Although the total number of institutions decreased in Metro-New York and upstate markets from 47 to 40 (Figure 1), market concentration has decreased 55 percent as measured by the Herfindahl-Hirschman Index (HHI). Used by the Department of Justice in order to analyze the competitive effects of bank mergers, HHI is determined by calculating sum of squared market shares of all banks in the New York State area. The highest level of concentration was 0.34 (3400) and the lowest 0.15 (1500), indicating "high concentration" in 2000 but "un-concentrated" markets in 2011. Paralleling reduced number of institutions, there has been a consolidation in total industry assets, as reflected in 29 percent decrease from $\$ 65$ billion in 1995 to $\$ 46$ billion in 2011. As shown in Figure 3, 5 S\&Ls account for 70.77 percent of total industry assets ( $\$ 46$ billion) in 2011.With the exception of Albany, the largest institutions are concentrated in the New York Metro area: Astoria, Flushing, Trustco, Dime-Savings and Provident Bank.

Albeit their smaller share of the market but large concentration in nonprime loans (Alt-A and subprime), federally insured S\&Ls suffered the greatest losses when the housing market collapsed in 2008. American Home Mortgage, which operated as a real estate investment trust, collapsed and filed for bankruptcy on August 6, 2007. In January 2008, Bank of America acquired Countrywide Financial, the largest U.S. mortgage lender, for $\$ 4$ billion after its stock prices had dropped $80 \%$ in value since 2007 (Morgenson, 2007; Mildenberg, 2008). In April 2007, New Century Financial Corporation, another real estate investment trust and second biggest U.S. mortgage lender, filed for bankruptcy after effectively reducing its labor force by $54 \%(\mathrm{CNN}, 2007)$.

There are fears that a reduced number of institutions would dampen market competition. There are also concerns that the remaining organizations are getting larger and the financial industry is becoming "too big to fail" again. Market concentration weakens competition (and consumer welfare) by fostering "collusive" behavior among banks and more than normal profits. Experts are divided over whether such collusion exists, and where they agree that it does, differ over the policyinterventions necessary to prevent it. The following review of literature highlights the debate around the underlying causes of bank performance and its relationship to market structures.

\section{A Brief Overview of Research on Market Concentration, Competition and Financial Performance}

There is a vast body of literature on the determinants of financial sector performance in different parts of the world (Short, 1979; Bourke, 1989; Berger et al, 1993; Berger, 1995a; 1995b; Goldberg and Rai, 1996; Demirguc-Kunt and Huizinga, 2000; Molyneux et al, 2004). Research on S\&L performance has primarily drawn from broader research across the entire banking industry (Brigham, 1964; Benston, 1972; Verbrugge et al., 1976; Geehan and Allen, 1978; Mester, 1993; Bradley, Gabriel and Wohar, 1995; Cebenoyan et al., 1995; Kaushik and Lopez, 1996; Jahere, Page and Hudson, 2006). The argument that market structures influence firm behavior is prevalent among 3 schools of thought: The Structure Conduct Performance (SCP) Paradigm, Efficient Structure Hypothesis (ESH) and Relative Market Power Hypothesis (RMPH). Market structures refer to market competition of firms (or lack thereof) and sectoral variables (concentration ratios; market growth) that are external to firm-level variables such as bank size, capital ratios, operating expenses, liquidity ratios, financial leverage and ownership structure (Rasiah, 2010:1-2; Athasanoglu et al., 2006:8).

As Molyneux et al (2004) note, the SCP paradigm flows from the oligopolistic theory of banking and the "collusive" behavior of firms. It is based on the proposition that the level of competition weakens in concentrated markets, fostering "collusion" among fewer firms and resulting in super-profits for the banking industry. This hypothesis suggests that market competition has a direct influence on profitability as measured by return on assets, return on equity and net interest margin. Banks operating in monopolistic markets charge higher interest on loans, lower rates on deposits, and higher fees than banks in competitive markets. The degree of concentration negatively impacts competition but is positively associated with profits regardless of firm specific efficiencies - the larger the market concentration, the less the degree of competition and higher the profits (Gilbert, 1984:618; Loyd-Williams et al, 1994:437).

The majority of early studies of the financial industry support the traditional SCP hypothesis (Short, 1979). In a representative study of North American, European and Australian banking markets, for example, Bourke (1989) 
found support for the traditional hypothesis of the positive relationship between collusive profits and concentration. Based on Bourke's approach in a pooled sample of European banks in 1986- 1989, Molyenux and Thornton (1992) showed that profits (pre-tax return on assets) are positively correlated with ten bank concentration ratio, payroll expenditures, nominal interest rates and government ownership. Their findings also lend support to the Edwards-Heggestad-Mingo hypothesis from the early SCP studies. In other words, banks with market power are more likely to display "expense preference" behavior. This type of behavior indicates that overhead expenses are beyond the profit maximizing level of competitive banks. Vennet's (1993) findings further indicate that in some European countries, Belgium, Ireland, Portugal and Spain, collusive profits prevail.

Related shortcomings of the SCP paradigm are summarized at greater length in Berger (1995b), Golberg and Rai (1996) and several others. In an important criticism of the SCP methodology, Gilbert (1984), Ruthenberg (1994) Goldberg and Rai (1996) note that bank regulation such as entry/exit barriers and direct efficiency measures tend to be neglected. For example, SCP should hold true in markets with greater entry barriers where market participants are effectively protected from competition. Widespread criticisms of neglected variables spurred two alternative explanations: The Relative Market Power Hypothesis (RMPH) and Efficient Structure Hypothesis (ESH). RMPH, which is a special variant of SCP, introduces "market share" as a proxy for the efficiency of firms. Profits increase in banks with larger market shares because of their ability to generate efficiency, which normally leads to higher market power. In this hypothesis, market share is positively related to firm-specific efficiencies (for example, through superior management and product differentiation), which also explains the positive relationship between concentration and profits. RMPH is supported when market share is positively related to profitability after controlling for the effects of concentration and efficiency. Additionally, higher profits do not always need to occur in concentrated markets (Goldberg and Rai, 1996:749). Smirlock (1985) introduces the market share as a proxy for firm-specific efficiency with a positive coefficient but finds that there is no relationship between concentration and profitability.

Goldberg and Rai (1996) draw a contrast to the two market-power theories (SCP and RMPH) through their Efficient-Structure-Hypothesis (ESH) that incorporates direct efficiency measures. They applied stochastic cost frontier approach, first proposed by Aigner et al (1977) and tested by Cebenoyan et al (1993) and Mester (1993) for the savings and loan industry. This approach derives measures of X-inefficiency and scale inefficiency and incorporates them directly into the tests under the Berger and Hannan (1993) model. Under the X-Efficiency (ESX) hypothesis, more efficient firms generate higher profits because they can produce a given combination output at minimum cost through superior management or technology. This gives efficient banks a "comparative advantage" to obtain additional profits regardless of the extent of market concentration and/or entry barriers. It is very likely that resulting market share leads to higher market concentration. Therefore, in this hypothesis, the direction of causality runs from efficiency to profits and market structures, not the other way around. When net interest margin is used as the measure of performance, however, efficiency measures are negatively correlated with performance because more efficient banks provide customers with more competitive loan and deposit rates (Goldberg and Rai, 1996:745-749). Under these assumptions, Goldberg and Rai find little support for the SCP hypothesis but they present evidence for one of the two versions of the ESH in 11 European countries in 1988-1991

In Berger's study (1995b) of 30 cross sections of 1980s banking data, the evidence lends partial support to X-efficiency version of ESH. A necessary condition for the ESH is that efficiency affects market structure, in other words efficient firms will capture higher profits and market share and will also be responsible for higher concentration. While X-efficiency is positively associated with profits in Berger, it is not sufficiently correlated with market share or concentration in order to support the profit-market structure relationship. On the other hand, Papadopoulou's analysis (2004) of European banking performance does not provide support for any of the assumptions of ESH, finding instead that efficiency and bank size are related (ie., "big banks are more X-efficient than small banks"). Similarly, Casu and Girardone (2006), who examined the competitive conditions of European banking for the period 1997-2003, note that the level of concentration is not related to the level of competition.

Recent evidence indicates that none of the hypotheses are fully adequate to explain bank profits, suggesting that alternative variables be tested. In the analysis of S\&L performance, selecting variables for resolving the differences between SCP and two versions of ESH presents challenges. Today thrifts are operating in an environment very different from the 1980s and 1990s. Profits vary not only by market types (bank-based versus market-based financial systems), but also between different sizes of banks, different services and ownership types, which may affect competitive conditions differently. For example, small banks are often regarded as "community banks" with different competitive advantages than large banks, such as serving more opaque and 
smaller borrowers and offering retail-oriented rather than wholesale businesses. Standard indices like HHI and CRn often treat the competitive advantages of different institutions equally, presenting "endogeneity problems" in bank performance analysis. This has invited the use of alternative measures of competition that include sunk costs and non-structural models like Panzar-Rosse statistic. As such, when examining the impact of market structures on profitability, researchers often incorporate regulation, the role of government, entry and exit barriers and other legal conditions for competition, such as shareholder rights, transparency, and trade openness among countries and within financial markets (Berger et al, 2004:436-437).

Furthermore, organizational forms can have a crucial effect on bank performance. Such forms include corporate governance structure, ownership and control and conflicts of interests between owners and managers. In a study of S\&L ownership structure, Akella and Greenbaum (1988) reveal that managers of mutual S\&Ls display greater expense preference behavior than managers of stock-holder S\&Ls. Their results are consistent with earlier SCP studies, indicating that mutual S\&Ls invest a high proportion of assets in loans and "source" a higher proportion of liabilities from deposits. Knopf and Teall (1996) examine the impact of ownership and regulation-the Financial Institutions and Reform and Recovery and Enforcement Act of 1989 (FIRREA)-on risk-taking behavior in the US thrift industry. This was a period of re-regulation aiming to increase capital ratios, regulate the use of brokered CDs and minimize real estate equity holdings. Their findings are consistent with classical agency theory that insider shareholders tend to pursue strategies that meet their own interests (utility) rather than the value of the firm. Increased risk activity in S\&Ls is associated with high levels of insider (management) shareholdings. This relationship is explained by the role of "entrenched managers". Such managers display more risk-taking behavior than institutional shareholders with more diversified portfolios. Furthermore, the ability of insiders to extract private benefits from outside interests (such as real estate development firms; lobby groups) may decrease return on assets and may negatively affect firm performance.

Based on the notion of managerial control, ownership and deregulation, other researchers evaluated the efficiency and profitability of S\&L institutions. The common finding has been that stock organizations are likely to be more effective than other types of organizations. Especially in the expense-preference theory, mutual thrifts are considered to be less efficient because they do not have greater access to capital and lack profit maximizing pressures from owners. Therefore, as Mester (1991) notes, mutual S\&Ls operate with "an inefficient output mix" which leads to conflicts of interest between owners and managers. For example, managers of mutual firms might be willing to sacrifice profit by making safer investments so as to reduce risk or maximize interests through "expense preference behavior".

While different ownership types influence performance differently, there is no clear consensus in the empirical literature as to whether mutual firms are less profitable than stockholder firms. In an important extension of Akella and Greenbaum's work (1988) using a much larger sample, Gropper and Hudson (2003) report evidence in favor of better managerial efficiency and decreasing expense-preference in S\&Ls that survived the financial crisis. This is due to the removal of barriers on competition rather than ownership type. In a stochastic cost frontier approach to a sample of 559 firms in Atlanta district, however, Cebenoyan et al (1993) report that there is no difference between the efficiency of joint stock and mutual thrifts.

The review in the preceding section discussed some of the factors influencing financial institution performance. The 3 hypotheses (SCP, RMPH, ESH) pertaining to this topic provide the useful framework for the performance analysis in this study. Additional problems, however, common to these theories concern the appropriate measure of market structure and performance. For example, SCP "offers no information on the absolute number or size distribution of firms necessary to exercise market power" (Evanofff and Fortier, 1988:280). While New York markets display regional characteristics that are hard to quantify, the SCP hypothesis should hold true in states with greater entry barriers. However, the ESH proposes that banks with efficient production should always reap higher profits regardless of the degree of concentration and entry barriers. This paper looks at how market structures and firm-level characteristics contribute to the performance of New York S\&Ls over the period 2000-2010. Our methodology incorporates some of the developments in econometrics, namely panel unit root and panel regression tests that may illuminate recent trends in the New York thrift markets.

\section{Data, Variables and Hypotheses}

This study employs multi-dimensional panel data over the period 2000-2011. Our data include time-series and cross-sectional information for all insured and regulated S\&L associations (40 as of 2011) in the New York State. The firm-level data, including the number of banking firms and all proxies, come from the Federal Deposit Insurance Corporation (FDIC) database: FDIC Institution Directory http://www2.fdic.gov/IDASP/main.asp. While there are missing values for some variables in our sample, each S\&L is observed every year. Thus we have 
used in our empirical work balanced panel data that amount to total observations of 420 .

Following the ratios used in previous studies, we identify the determinants of S\&L associationperformance as follows. The performance measure chosen is bank "profit" measured as return on assets (ROA). ROA is "annualized net income including gains or losses on securities and extraordinary items" divided by average total assets (FDIC, 2002). We have decided not to use return on equity (ROE) $=$ Net Income/Total Equity as the dependent variable because some banks contain negative equity. While ROA and ROE have been used in most studies, other studies have also used net interest margin (NIM) as a proxy for the "pricing ability of banks" for deposits and loans. If the SCP hypothesis holds true, then the net interest margin will be higher. NIM indicates the ability of monopolistic banks to charge lower deposit rates and higher loan rates (Goldberg and Rai, 1996:752). However, individual prices may not always be a reliable profit measure because banking is a multi-product industry and pricing strategies differ across banks and across markets. Banks are likely to cross-subsidize in the presence of regulations (Evanoff and Fortier, 1988: 281). Use of the profit measure as ROA should filter some of these potential problems.

The independent variables include both market-specific (microeconomic/industry-related) and firm-level variables and are similar to those utilized in previous studies. In analyzing market structure, we consider New York State to be a market. The SCP and efficient structure hypotheses are tested by the addition of market structure variables--concentration ratios-and firm-specific market shares (MS) defined as ratio of each bank's deposits-to-total industry deposits. We have employed the two popular measures of concentration--the four-bank concentration ratio (CR4) and the Herfindahl Hirschman Index (HHI). While MS captures firm-efficiency (Relative Market Power Hypothesis), CR4 and HHI are market structure indicators. CR4 is defined as the ratio of total deposits of the four largest S\&Ls to the total deposits of all S\&Ls in the New York state. Similarly, HHI is defined as the sum of squared market shares of deposits of all the S\&Ls. But since CR4 does not use market shares of all banks in the industry, we prefer to use HHI as an indicator of market structure. HHI provides a more comprehensive picture by giving weight to each bank's market share. Logarithm of total assets (the proxy for size-induced scale economies), while being insignificant in all regressions, is excluded for causing inter-correlation with MS.

Several control variables are introduced to account for firm-level risk and managerial efficiency. Since performance measure ROA is not risk adjusted, we employ three variables to account for differing leverage, credit and liquidity risks among firms. EQV, equity capital-to-asset ratio, indicates the level of leverage used by a company (bank risk) and relative portion of the equity used to finance a company's assets. We expect the relationship between leverage and profit to be both negative and positive. Higher equity ratio indicates more capital and less leverage, which could result in decreased borrowing costs. Firms with lower borrowing costs can become more profitable. Conversely, lower equity ratio or "higher leverage indicates aggressive asset/liability management which leads to higher interest margins (NIM) and profits" (Golberg and Rai, 1996:757). LIQ, average loan-to-average asset ratio, measures the riskiness of loans since loans are riskier and generate higher returns (ROE or ROA) than other assets such as government securities (Evanoff and Fortier, 1988:282). Therefore, a positive relationship ties liquidity and profitability. On the other hand, higher loan-to-asset ratio can also decrease profitability by increasing bank risks.

Following Athasanoglu et al (2006) and Pervan et al (2009), we use CRIS1, loan loss provision-to-loan ratio, as a proxy for credit/default risk and asset quality. Each year, banks set aside"loan loss provision" as an allowance for bad loans (customer defaults, unpaid loans, non-performing loans, etc.). The amount of provisions set aside increases with the riskiness of the loans. A bank having a larger loan loss provision makes a large amount of risky or poor loans compared to a bank setting aside smaller amount. Credit risk affects the performance of an institution since increased risk is normally associated with decreased profitability. Poor asset quality is one of the main causes of bank failures (Miller and Noulas, 1997). On the other hand, higher ratio of allowance for bad loans can affect profitability positively; banks with a large number of risky loans can charge higher interest rate for the likelihood of higher customer default. Therefore, while the coefficient of CRIS1 is expected to be negative, it can also be positive.

EEFR is the operating efficiency ratio available in the FDIC database as a bank-specific variable. We have used this ratio as a proxy for managerial and operating efficiency. EEFR is defined as "noninterest expense minus foreclosed property expense minus amortization of intangibles, expressed as a percentage of the sum of net interest income plus noninterest income" and reflects the "proportion of net operating revenues absorbed by overhead expenses" (FDIC, 2002). Since EEFR is an operating cost ratio, we expect the coefficient sign to be negative under the Efficient Structure Hypothesis (ESH). Lower ratio indicates lower overhead costs and greater operating efficiency of the institution, which could then result in higher profits. 
While NIMY, the net interest margin, was used in previous studies as a proxy for performance (Angbazo, 1997; Demirguc-Kunt and Huiziga, 1999; 2000; Goldberg and Rai, 1996), this study uses it as a right-hand side variable. NIMY is the difference between interest income and interest expense as a percentage of interest bearing assets (FDIC, 2002). Demirguc-Kunt and Huizinga (2000) point out that profits and netinterest margins are higher in countries with lower levels of economic growth whereas the impact of growth on profits is exhausted in developed financial systems (countries with higher levels of GDP per capita). Banking research indicates that banks in highly concentrated markets charge higher rates on loans, and pay lower rates on deposits than banks in more competitive markets. Therefore, net interest margins and profits decrease as competition increases. In addition, Smirlock (1985) stresses that interest rate spreads are narrower in concentrated banking industry whereas Angbazo (1997) finds that higher net interest margins are associated with more risky loans and higher interest-rate risk exposure. Different types of risks are associated with "concentration in short-term assets and off-balance sheet hedging (OBS) instruments".

\section{Econometric Methodology}

Following Evanoff and Fortier (1988) and Lloyd-Williams et al (1994:438), we present the following equations to test the competing hypotheses for the New York State S\&L associations. The reduced form of profit equation is displayed below:

$$
\operatorname{PROFIT}_{i t}=\alpha_{0}+\alpha_{1} I_{t}+\alpha_{2} M S_{i t}+\sum_{\alpha i} X_{i t}
$$

where PROFIT $_{i t}$ is a performance measure (ROA) for the firm $i$ during the period $t$; $\mathrm{X}$ is a vector of control variables, which are intended to account for firm- specific variables for bank $i$ at time $t ; I_{t}$ is a measure of market structure, usually a concentration measure HHI $\left(\sum_{s i} S_{t}^{2}\right)$--sum of squared market shares $(S)$ of all banks at time $t$ and accounts for industry/market-specific characteristics. $M S_{i t}$ is market share for firm $i$ during the period $t$ and used for controlling firm-specific efficiencies. $\varepsilon_{t}$ captures the random error or disturbance in time denoted by white noise (residual), $\alpha_{i}$ the unobserved individual (bank-specific or "entity fixed effect") and $u_{i t}$ the remainder of the disturbance or error term. An unobserved variable varies from one bank to the other but is constant over time. We want to estimate $Y_{R O A}$ (PROFIT), the effect on $\mathrm{Y}$ of $\mathrm{X}$ holding constant unobserved bank characteristics. In the fixed-effect model, this can be interpreted as having $n$ intercepts one for each entity with the constant slope for all entities (Stock and Watson, 2011:354).

In the augmented regression equation below, the traditional SCP hypothesis holds true if $\alpha_{1}>0$ and $\alpha_{2}=0$; and the efficiency hypothesis (ESH) if $\alpha_{1}=0$ and $\alpha_{2}>0$ (Lloyd-Williams et al, 1994:438).

$$
\begin{aligned}
& \ln \text { PROFIT }_{i t}=\alpha_{0}+\alpha_{1} \ln H H I_{t}+\alpha_{2} \ln M S_{i t}+\alpha_{3} \ln E Q V_{i t}+\alpha_{4} \ln L I Q_{i t}+\alpha_{5} \ln E E F F R_{i t}+ \\
& \alpha_{6} \ln C R I S 1_{i t}+\alpha_{7} \ln N I M Y_{i t}+\varepsilon_{i t} \\
& \varepsilon_{i t}=\alpha_{i}+u_{i t}
\end{aligned}
$$

where all the variables are expressed in natural logarithms:

Log of PROFIT= bank $i$ 's profit measured as the return on assets (ROA)

Log of $H H I=$ concentration ratio in the New York State savings and loan industry (Herfindahl-Hirschman Index)

$\log$ of $M S=$ market share measure, total deposits of each bank-to-total deposits of industry ratio

Log of $E Q V=$ Equity capital-to-asset ratio (bank risk/leverage/capitalization)

$\log$ of $L I Q=$ Average loan-to-average asset ratio (liquidity risk)

$\log$ of $E E F F R=$ Noninterest expense-to-sum of net interest income and noninterest income ratio

Log of CRIS1=Loan loss allowance-to-loans ratio (credit risk)

Log of NIMY=Interest income minus interest expense-to-earning assets ratio (net interest margin)

With respect to the testing procedure, we apply both the Panel Least Squares method of fixed effects (FE) and Panel Estimated Generalized Least Square (PEGLS) method of random effects (RE). Fundamentally, both panels are applications of the OLS estimator to the augmented equation displayed above. While both of the models allows for cross-sectional and time-series effects (Baltagi, 2001), there is a need to control heterogeneity in units 
of observation. In the fixed effects (FE) model, unobserved individual heterogeneity (firm-level characteristics) varies from bank to bank (different intercepts) but do not vary across time (constant slope). In the random effects model (PEGLS), however, there are no fixed or individual effects and heterogeneity in units of observation is uncorrelated with the independent variables (Yaffe, 2006). PEGLS has the advantage of generalizing beyond the sample in the analysis. Following a procedure advanced in previous studies, we use the Hausman (1978) specification test to determine which effect to use.

Before applying the Hausman test, however, we pretest if all variables are integrated of order one in levels. Variables with unit root exhibit trending or non-stationary behavior leading to spurious relationships between the explanatory and outcome variables (Cromwell, Labys \& Terraza, 1994:23). Therefore, it is important to check whether the variables included in our models contain a unit root. Several panel unit root tests are used for verifying the non-stationary of the variables--for instance, Levin, Lin and Chu (LLC) (2002), Breitung (2000), Im Pesaran and Shin (IPS) (2003), and Fisher-type tests using ADF and PP tests. While LLC and Breitung tests assume a common unit root process, $\alpha=\rho-1$, where the lag orders for the difference terms $\left(\rho_{i}\right)$ are identical across sections, IPS, Fisher-ADF and Fisher-PP allallow for individual unit root processes so that $\rho_{i}$ varies across sections. In LLC and Breitung, a null hypothesis of unit root for the common process, $H_{0}: \alpha=0$, is tested against the alternative hypothesis of no unit root, $H: \alpha<0$. A unit root test renders the data stationary by applying first or second difference operator to the OLS estimator. We have selected the optimal length automatically using the Schwarz criterion. Individual intercepts and trend terms, which include both fixed effects and trends, are included in the test equation.

\section{Results and Discussion}

This section discusses the results of the empirical analysis. First, it reviews the descriptive statistics of test data. Next it evaluates the inferential statistics in order to reject or accept the competing hypotheses (SCP, RMPH, ESH) discussed in the previous section.

As descriptive statistics indicate, the continuing US economic downturn highlights some of the trends in ROA. Based on the average of cross-sections, the highest profitability is in 2002 and lowest in 2009. The maximum value corresponds to the beginning of real estate bubble and lowest value to the height of subprime mortgage crisis. The cyclical component of time-series indicates that profitability reached the highest levels during the housing boom (2000-2004) and then started to decrease after 2005. During 2000-2010, market concentration of firms averaged around 0.2344 as measured by HHI Index. An HHI index between 0.15 and 0.25 (or 1,500 to 2,500 ) indicates moderate concentration or oligopolistic competition. While the average concentration of 0.23 may support the hypothesis of collusive profits in the New York State, there is a general trend of decreasing concentration, as indicated by highest value in 2000 (0.34) and lowest (0.15) in 2011.

Low standard deviations indicate that the data points are not highly variable or dispersed. Whereas high deviation implies that the data points are spread out over a large range of values, low deviation indicates that data points tend to be close to the mean; there are no outliers in the data set. The standard deviation of HHI shows some statistical dispersion in data used for measuring concentration. This highlights the variation in sample size supporting the trend line in Figure 2. Table 2 summarizes the Pearson correlation coefficient of test data among independent variables. The estimated correlation coefficients show that there is no high-level correlation among variables included in the regression analysis. In other words, independent variables are not correlated to a degree to create multi-collinearity problem.

Time series panel unit root tests are reported in Table 3. Based on an automatic selection of optimal lag value, our tests confirm that all natural logarithm of variables except net interest margin (NIMY) contain unit roots. All variables seem to be stationary in first differences, while non-stationary in levels. Only LIQ is stationary in second difference. ROA fails the Breitung test in common root, but passes other tests in first difference. Based on the results of five panel unit root tests, all the variables in the model are integrated of order one and thus rendered stationary.

Table 4 reports the results of Hausman misspecification test. This test determines whether our model is appropriate for panel data analysis and it is free of misspecification. The null hypothesis of no misspecification is tested against the alternative of misspecification. The results indicate no evidence to reject the null hypothesis of no correlation between unobserved random error and independent variables. In other words, with the test probability ( $\mathrm{p}$ value 0.0866 ) greater than the critical value of 0.05 , it is appropriate to use the random effect model instead of the fixed effect model.

Returning to inferential statistics, all ROA based regressions provide evidence of the impact of firm-specific 
variables on bank performance. Results of the random effect panel regression are reported in Table 5, which are based on 420 observations. When all variables are included for the final estimation, the regression model is significant at $\mathrm{p}$ value based on Probability (F Statistic). Probability (F Statistic) measures whether the relationship between the control variables and dependent variable is significant. Overall regression function has an explanatory power of 24 percent presented by R-squared; right hand side variables explain the dependent variable by 24 percent and the $\mathrm{F}$ statistic supports the regression. Overall, our regression model is significant at a level lower than 5 percent, so we can be reasonably confident that the good fit of the equation is not due to chance.

The traditional SCP hypothesis holds true if $\alpha_{1}>0$ and $\alpha_{2}=0$; and the efficiency hypothesis (ESH) if $\alpha_{1}=0$ and $\alpha_{2}>0$ (Lloyd-Williams et al, 1994:438). Both of these conditions must be satisfied in order to accept market structure theories unconditionally. Although the coefficient of HHI (absolute value) is different than 0 , market share does not equal zero. Therefore, SCP is rejected. When controlling the effect of HHI, on the other hand, MS is still insignificant and fails to reject the RMPH that market share of firms determine profitability regardless of the degree of market concentration. ESH would be supported if efficiency, through the market share variable, were significantly correlated with profitability. Overall, none of the market power hypotheses (SCP, RMPH, ESH) support the importance of market structures as an explanation of firm performance in the New York S\&L industry. Neither market share of individual firms nor market concentration has meaningful associations with profitability.

The profitability of New York S\&L associations is dependent on several firm-level characteristics rather than market structures. When we add up market shares and microeconomic variables to the first model, effects of bank level variables do not change that much. More efficient banks are more profitable as indicated in Table 5 . As the ratio of operational costs to total assets (EEFFR) increases by one point, the profitability of banks decrease by 0.001 points. Although market share is not significantly related to profitability in order to support ESH unconditionally, the significance of firm-level efficiency gives partial support to ESH. At the micro-level, efficiency is captured from cost saving advantages related to firm-specific/managerial efficiencies rather than market shares. While we expect efficient firms to capture higher market share, results do not necessarily support this conclusion.

Most importantly, our results show that risk is an important component of bank profits. While successful banks are more profitable, they are not less risk free. The role of risk is expressed through the incorporation of liquidity risk and credit risk variables. As banks become more risky (LIQ), their profits decrease in all regressions, as evident in decrease in return on assets (ROA) by 0.02 points. Riskier loans generate more lucrative returns than other assets such as government securities. Therefore, one would expect a positive relationship between LIQ and ROA. However, too much liquidity can also decrease profitability by exposing banks to credit risks, interest rate risks, defaults risks, etc. Likewise, credit risk (CRIS1), defined as ratio of loss allowance-to-total loans, can be the primary risk in the banking system. The loan loss provision set aside each year increases with the riskiness of the loans. A bank having a low loan loss provision makes a small amount of risky loans compared to a bank committed to a higher provision. As indicated in Table 5, credit ratio and profitability are inversely related, suggesting that S\&Ls might be making risky loans. Management of credit risk is essential to bank performance; in fact, capital depletion through loan losses has been the proximate cause of most bank failures in the recent crisis.

Unexpectedly, net interest margin has no impact on profitability in any of the regressions. Previous research indicates that net interest margins are high in concentrated markets where collusive profits exist. Interest margins decrease with more fragmentation and development of competitive conditions in banking markets. Although the coefficient of NIMY becomes more significant after introducing HHI, it is still insignificant statistically.

Finally, capitalization (EQV) is inversely related to profitability. According to the literature, the coefficient of EQV can be both positive and negative. Higher ratio of equity-to-total assets indicates more capital and less leverage, which could result in decreased borrowing costs and thus higher profits. Conversely, lower ratio indicates more leverage and more aggressive asset liability management, which may lead to higher return on assets. Unlike debt capital, which is raised by incurring debt through the issuance of bonds, equity capital is invested money raised from owners of the company. The coefficient of EQV is compatible with the second explanation emphasizing inverse relationship. 1 unit increase in capitalization leads to 0.06 units decrease in profits. Similarly, 1 unit decrease in capitalization is associated with 0.06 units increase in profits.

Given that market share (MS) is insignificant in all regressions, it fails to support the ESH that profit is related to greater market share related to firm-specific efficiencies rather than market concentration. On the other hand, 
efficiency (operating cost) influences performance regardless of market share, lending partial support to the ESH. This formulation provides more evidence in favor of the ESH than the SCP hypothesis. The coefficient of HHI is in contrast with the studies that supported the structure-performance relationship (Molyneux, 1992, Lloyd-Williams et all, 1994) and is more compatible with recent work supporting neither version of ESH (see Papadopoulos, 2004).

\section{Policy Implication of Empirical Findings}

Our results have certain implications for regulatory treatment of S\&L associations in New York State. Since the SCP hypothesis finds a positive relationship between concentration and profits, it cautions against mergers and acquisitions and proposes policy interventions (anti-trust) to break up concentration. By contrast, ESH sees no role for anti-trust or government intervention in bank mergers. Proponents of ESH assume that efficient banks can "improve their market shares by providing more economical banking services in the market" (Seelanatha, 2010: 20). Therefore, in ESH paradigm, there is no need to employ anti-trust policy in order to improve market efficiency. Our results do not support the policy implications of either theory. There is some evidence to support the conclusion that New York S\&L markets are sufficiently competitive. Neither market concentration nor market shares explain profits. Therefore both SCP and ESH are rejected.

While on average HHI remains close to oligopolistic competition in descriptive statistics, it has no impact on profit margin in regression analysis. Overall, New York markets appear to remain sufficiently diversified and non-concentrated. Given that profitable institutions are efficient, it can be concluded that S\&Ls enjoy firm-specific advantages (cost saving); additional policies may be warranted in the future in order to maintain competitive advantage and prevent any abuse of market power and extra profits of the largest banks. Such approach should foster healthy market competition among firms allowing competitive and economical services for their clients.

Our analysis further indicates that risk appears to be the most important component of bank performance. Therefore, to maintain competitive advantage related to firm-specific efficiencies it is necessary to control risk and mitigate the pro-cyclicality of bank profits in un-concentrated markets. One option is the application of more robust internal and external risk rating processes. Policy interventions are warranted to increase the effectiveness of risk management and measurement at the firm and industry levels. FDIC and OCC are taking action to regulate risk more thoroughly, although it is too soon to tell the outcome. Overall, our results suggest policy makers to focus on prudential regulations, adequate level of capitalization against losses and improvements in risk management systems, which can enhance the performance of remaining S\&Ls in the New York State.

\section{Summary and Conclusions}

The S\&L industry has experienced poor performance as indicated by massive loan losses, mortgage defaults and institutional failures throughout the 1980s and 1990s. This paper analyzed the determinants of profitability using firm-specific and industry-specific data for the most recent period 2000-2010. It tested the market structure-performance hypotheses (SCP and $\mathrm{ESH}$ ) for all S\&L associations in the New York State. Using data from Federal Deposit Insurance Corporation (FDIC), we have utilized a total number of 420 observations across 40 financial institutions.

Overall, our results show that while credit risk undermines profitability (higher credit risk leads to lower return on assets), capitalization tends to weaken profits. A higher ratio of loan loss provisions-to-total assets (CRIS1) indicates the presence of S\&Ls with riskier loans, and hence less profit. None of the market power hypotheses (SCP, RMPH, ESH), however, support the importance of market structures as an explanation of profitability in the S\&L sector. Neither market share of individual firms nor market concentration has meaningful associations with return on assets. On average, New York S\&L markets appear to remain diversified and modestly competitive in the period 2000-2010. In this regard, anti-trust policies are not a sine qua non since market concentration is relatively insignificant. However, this does not invalidate the need for anti-trust, which prevails to avert market power that may be associated with mergers and acquisitions.

Overall, evidence indicates that S\&L profits are vulnerable to credit risks at the firm level. This suggests that it is crucial to control the pro-cyclicality of firm profitability in a less concentrated market. Capitalization has an inverse relationship with profitability. This implies that banks need to develop risk control systems that are flexible enough to absorb loan related risks without hindering earnings. Risk management should go hand in hand with adequate level of capitalization. Subsequently, a higher allowance for non-performing loans in normal times and lower amount in bad times can mitigate the impact of credit risk on ROA. The topic of prudential regulation includes how to subject banks to such provisions that might increase their operational costs. Also in 
ROA specification, an important negative effect on profitability was caused by operational costs--the managerial efficiency variable. In other words, banks which pay more attention to cost control gain more profits.

Future research is necessary to test different measures of efficiency on profitability. A potentially useful direction is to derive direct measures of X-efficiency and Scale-efficiency that more accurately account for the relevant market. In order to derive them, some researchers used Data Envelopment Analysis (DEA). Also known as non-parametric method, DEA is used for the estimation of productive efficiency of different units in industrial organization studies. Likewise, future research can benefit from the correction of an endogeneity problem also known as "omitted variables" bias. Inclusion of legal, political and other institutional variables can highlight the impact of "regime change" on profit margins. GDP was excluded from the analysis given that all banks operate in the same macroeconomic environment. Inclusion of other control variables, however, can better reveal the performance of S\&L sector in the New York State.

\section{References}

Aigner, D., Lovell, C. A. K., \& Schmidt, P. (1977). Formulation and Estimation of Stochastic Frontier Production Function Models. Journal of Econometrics, 6, 21-37. http://dx.doi.org/10.1016/0304-4076(77)90052-5

Akella, S. R., \& Greenbaum, S. I. (1988). Savings and Loan Ownership Structure and Expense Preference Behavior. Journal of Banking and Finance, 12, 419-437. http://dx.doi.org/10.1016/0378-4266(88)90007-6

Angbazo, L. (1997). Commercial bank net interest margins, default risk, interest-rate risk, and off-balance sheet banking. Journal of Banking and Finance, 21, 55-87. http://dx.doi.org/10.1016/S0378-4266(96)00025-8

Athasanoglu, P. P., Delis, M. D., \& Staikouras, C. K. (2006). Determinants of Bank Profitability in the South Eastern European Region. Working Paper, Bank of Greece, Economic Research Department, No.47, September.

Balderston, F. E. (1985). Thrifts in Crisis: Structural Transformation of the Savings and Loan Industry. Real Estate Economics, 14(1), 165-168

Baltagi, B. (2001). Econometric Analysis of Panel Data. John Wiley and Sons: Chichester.

Barth, J. R. (1991). The Great Savings and Loan Debacle. American Enterprise Institute Press.

Benston, G. J. (1972). Economies of Scale of Financial Institutions. Journal of Money, Credit and Banking, 4(2), 312-341. http://dx.doi.org/10.2307/1991041

Benston, G. J. (1986). Federal Regulation of Banking: Historical Overview, in Deregulating Financial Services: Public Policy in Flux, edited by George G. Kaufman and Roger C. Kormendi. Ballinger Publishing Company: Cambridge, Mass.

Berger, A. N. (1995a). The relationship between capital and earnings in banking. Journal of Money, Credit and Banking, 27(2), 432-456. http://dx.doi.org/10.2307/2077877

Berger, A. N. (1995b). The profit-structure relationship in banking: Tests of market power and efficient structure hypotheses. Journal of Money, Credit and Banking, 27(2), 404-431. http://dx.doi.org/10.2307/2077876

Berger, A. N., \& T. Hannan. (1993). Using efficiency measures to distinguish among alternative explanations of the structure-performance relationship in banking, Federal Reserve Board working paper.

Berger, A. N., Demirguc-Kunt, A., Levine, R., \& Haubrich, J. G. (2004). Bank Concentration and Competition: An Evolution in the Making. Journal of Money, Credit and Banking, 36(3), 433-451. http://dx.doi.org/10.1353/mcb.2004.0040

Berger, A. N., Hunter, W. C., \& Timme, S. G. (1993). The Efficiency of Financial Institutions; A Review and Preview of Research Past, Present and Future. Journal of Banking and Finance, 17, 221-249. http://dx.doi.org/10.1016/0378-4266(93)90030-H

Bourke, P. (1989). Concentration and Other Determinants of Bank Profitability in Europe, North American and Australia. Journal of Banking and Finance, 13, 65-79. http://dx.doi.org/10.1016/0378-4266(89)90020-4

Bradley, M. G., Gabriel, S. A., \& Wohar, M. E. (1995). The Thrift Crisis, Mortgage-Credit Intermediation, and Housing Activity. Journal of Money, Credit and Banking, 27(2), 476-497. http://dx.doi.org/10.2307/2077879

Breitung, J. (2000). The local power of some unit root tests for panel data. In B. H. Baltagi (Ed.), Nonstationary Panels, Panel Cointegration, and Dynamic Panels. Advances in Econometrics, 15, 161-17. http://dx.doi.org/10.1016/S0731-9053(00)15006-6

Brigham, E. (1964). Economies of Scale in the Savings and Loan Industry. Economic Inquiry, 3(1), 7-20. http://dx.doi.org/10.1111/j.1465-7295.1964.tb00900.x 
Casu, B., \& Girardone, C. (2006). Bank Competition, Concentration and Efficiency in the Single European Market. The Manchester School, 74(4), 441-468. http://dx.doi.org/10.1111/j.1467-9957.2006.00503.x

Cebenoyan, A. S., Cooperman, E. S., \& Register, C. A. (1995). Deregulation, Reregulation, Equity Ownership, and S\&L Risk-Taking. Financial Management, 24(3), 63-76. http://dx.doi.org/10.2307/3665558

Cebenoyan, A. S., Cooperman, E. S., Register, C. A., \& Hudgins, S. C. (1993). The relative efficiency of stock versus mutual S\&Ls: A stochastic cost frontier approach. Journal of Financial Services Research, 7(2), 151-170. http://dx.doi.org/10.1007/BF01046903

CNN. (2007). New Century files for Chapter 11 Bankruptcy, April 3.

Cromwell, J. B., Labys, W. C., \& Hannan, M. J. (1994). Multivariate Tests for Time- Series Models. Sage Publications.

Curry, T., \& Shibut, L. (2000). The Cost of the Savings and Loan Crisis: Truth and Consequences. FDIC Banking Review, 12, 26-35.

Demirguc-Kunt, A., \& Huizinga, H. (1999). Determinants of commercial bank interest margins and profitability: some international evidence. World Bank Economic Review, 13, 379-408.

Demirguc-Kunt, A., \& Huizinga, H. (2000). Financial Structure and Bank Profitability. The World Bank in its series Policy Research Working Paper Series with number 2430 [On line August 31, 2000] Available at http://ideas.repec.org/p/wbk/wbrwps/2430.html [accessed: March 5, 2011].

Ely, Bert. (2008). Savings and Loan Crisis. The Concise Encyclopedia of Economics. Also available at http://www.econlib.org/library/Enc/SavingsandLoanCrisis.html

Evanoff, D., \& Fortier, D. L. (1988). Revaluation of the Structure-Conduct-Performance Paradigm in Banking. Journal of Financial Services Research, 1, 277-294. http://dx.doi.org/10.1007/BF00114854

FDIC. (2002). Ten Largest Thrift Companies: Glossary. Available at http://www.fdic.gov/bank/analytical/thriftlargest/2002may/ [accessed: October 6, 2011].

Fraser, D. R., \& Zardkoohi, A. (1996). Ownership Structure, Deregulation and Risk in the Savings and Loan Industry. Journal of Business Research, 37, 63-69. http://dx.doi.org/10.1016/0148-2963(96)00027-6

Geehan, R., \& Allen, L. (1978). Measuring the real output and productivity of savings and credit institutions. The Canadian Journal of Economics, 11(4), 669-679. http://dx.doi.org/10.2307/134372

Gilbert, R. A. (1984). Bank Market Structure and Competition: A Survey. Journal of Money, Credit and Banking, 16(4), 650-656.

Golderberg, L. G., \& Rai, A. (1996). The structure-performance relationship for European banking. Journal of Banking \& Finance, 20(4), 745-771.

Gropper, D. M., \& Hudson, C. D. (2003). A note on savings and loan ownership structure and expense preference: A re-examination. Journal of Banking and Finance, 27, 2003-2014. http://dx.doi.org/10.1016/S0378-4266(02)00315-1

Hausman, J. A. (1978). Speficiation Tests in Econometrics. Econometrica, 46(6), 1251-1271. http://dx.doi.org/10.2307/1913827

Hudson, Mike. (2008). IndyMac: What Went Wrong? How An Alt-A Leader Fueled its Growth With Unsound and Abusive Mortgage Lending, Center for Responsible Lending, CRL Report, June 30.

Im, K. S., Pesaran, M. H., \& Y. Shin. (2003). Testing for Unit Roots in Heterogenous Panels. Journal of Econometrics, 115, 53-74. http://dx.doi.org/10.1016/S0304-4076(03)00092-7

Jahera, J. S., Page, D. E., \& Hudson, C. D. (2006). Financial Condition and Performance of Savings and Loans: A Retrospective Look at Mutual to Stock Conversions. Investment Management and Financial Innovations, $3(2), 77-87$.

JithJayaratne, J., \& Hall, C. (1996). Consolidation and Competition in Second District Banking Markets. Current Issues, Federal Reserve Bank of New York, 2(8).

Kane, Edward J. (1989). The S\&L Insurance Mess: How Did it Happen? Urban Institute Press.

Kaushik, S. K., \& Lopez, R. H. (1996). Profitability of Credit Unions, Commercial Banks and Savings Banks: A Comparative Analysis. The American Economist, 40(1), 66-78. 
Knopf, J. D., \& Teall, J. L. (1996). Risk-taking behavior in the US Thrift Industry: Ownership Structure and Regulatory Changes. Journal of Banking and Finance, 20, 1329-1350. http://dx.doi.org/10.1016/0378-4266(96)00010-6

Levin, A., C. F. Lin, \& C. Chu. (2002). Unit Root Tests in Panel Data: Asymptotic and Finite-Sample Properties. Journal of Econometrics, 108, 1-24. http://dx.doi.org/10.1016/S0304-4076(01)00098-7

Lloyd-Williams, D. M., Molyneux, P., \& Thornton, J. (1994). Market Structure and Performance in Spanish Banking. Journal of Banking and Finance, 433-443. http://dx.doi.org/10.1016/0378-4266(94)90002-7

Mester, L. J. (1991). Agency Costs Among Savings and Loans. Journal of Financial Intermediation, 1, 257-278. http://dx.doi.org/10.1016/1042-9573(91)90010-W

Mester. L. J. (1993). Efficiency in the Savings and Loan Industry. Journal of Banking and Finance, 17(2-3), 267-286. http://dx.doi.org/10.1016/0378-4266(93)90032-9

Mildenberg, D. (2008). Bank of America to Acquire Countrywide for \$4 billion. Bloomberg, January 11.

Miller, S., \& Noulas, A. (1997). Portfolio Mix and Large Bank Profitability in the USA. Applied Economics, 29, 505-512. http://dx.doi.org/10.1080/000368497326994

Mishkin, F. (1999). Financial Consolidation: Dangers and Opportunities. Journal of Banking and Finance, 23, 675-691. http://dx.doi.org/10.1016/S0378-4266(98)00084-3

Molyneux, P., \& Thornton, J. (1992). Determinants of European Bank Profitability: A note. Journal of Banking and Finance, 16(6), 1173-1178. http://dx.doi.org/10.1016/0378-4266(92)90065-8

Molyneux, P., Goddard, J., \& Wilson, J. O. S. (2004). The Profitability of European Banks: A Cross-Sectional and

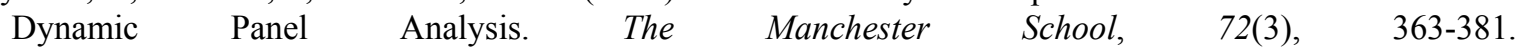
http://dx.doi.org/10.1111/j.1467-9957.2004.00397.x

Morgenson, G. (2007). Inside the Countrywide Lending Sphere. New York Times, August 26.

Paletta, D., \& Enrich, D. (2008). Crisis Deepens as Big Bank Fails. Wall Street Journal, July 12.

Papadopoulos, S. (2004). Market Structure, Performance and Efficiency in European Banking. International Journal of Commerce and Management, 14(1), 9-100. http://dx.doi.org/10.1108/10569210480000175

Pervan, M., Pervan, I., \& Guadagnino, A. (2009). Market Structure and Performance of Croatian Commercial Banks. Paper presented at July 2009 Business and Economics Society International Conference, July 15-18, Kona-Hawaii, USA.

Rasiah, D. (2010). Review of Literature and Theories on Determinants of Commercial Bank Profitability. Journal of Performance Management, 23(1), 23-49.

Ruthenberg, D. (1994). Structure-performance and economies of scale in banking in a unified Europe. Banking Review, 4, Bank of Israel (June), 95-114.

Seelanatha, Lalith. (2010). Market Structure, Efficiency and Performance of Banking Industry in Sri Lanka. Banks and Bank Systems, 5(1).

Short, B. K. (1979). The Relation Between Commercial Bank Profit Rates and Banking Concentration in Canada, Western Europe and Japan. Journal of Banking and Finance, 3, 209-219. http://dx.doi.org/10.1016/0378-4266(79)90016-5

Smirlock, M. (1985). Evidence of the non-relationship between concentration and profitability in Banking. Journal of Money, Credit and Banking, 17(1), 69-93. http://dx.doi.org/10.2307/1992507

Verbrugge, J. A., Shick, R. A., \& Thygerson, K. J. (1976). An Analysis of Savings and Loan Profit Performance. The Journal of Finance, 31(5), 1427-1442. http://dx.doi.org/10.2307/2326689

Watson, M. W., \& Stock, J. H. (2011). Introduction to Econometrics. Pearson.

Wheelock, D. C. (2011). Have Acquisitions of Failed Banks Increased the Concentration of US Banking Markets? Federal Reserve Bank of St. Louis Review, May/June, pp.155-169.

Yaffe, R. (2006). A Primer for Panel Data Analysis. Available at http://www.nyu.edu/its/pubs/connect/fallo3/yaffee_primer.html [accessed: October 6, 2011 


\section{Appendix}

Table 1. Descriptive Statistics of Test Data

\begin{tabular}{l|cccc}
\hline \multicolumn{1}{c|}{ Variables } & Symbol & Mean & Std. Dev. & Max. \\
\hline Profitability & ROA & 0.0045 & 0.0134 & 0.0396 \\
Capitalization & EQV & 0.1250 & 0.0679 & 0.8002 \\
Liquidity Risk & LIQ & 0.6447 & 0.2088 & 0.9448 \\
Efficiency & EEFFR & 0.8522 & 0.6615 & 56.607 \\
Market Share & MS & 0.0259 & 0.0736 & 0.5776 \\
Credit Risk & CRIS1 & 0.0083 & 0.0071 & 0.063 \\
Concentration Ratio & HHI & 0.2344 & 0.0556 & 0.0001 \\
\hline
\end{tabular}

Table 2. Correlation Among Independent Variables

Sample: 2000-2011

Included observations: 462

Balanced sample

\begin{tabular}{|c|c|c|c|c|c|c|c|}
\hline Correlation & EQV & LIQ & EEFFR & MS & CRIS1 & NIMY & $\mathrm{HHI}$ \\
\hline EQV & 1.000000 & & & & & & \\
\hline LIQ & -0.271738 & 1.000000 & & & & & \\
\hline EEFFR & 0.264956 & -0.174112 & 1.000000 & & & & \\
\hline MS & -0.171680 & 0.010380 & -0.045992 & 1.000000 & & & \\
\hline CRIS1 & -0.064237 & -0.140786 & 0.015326 & 0.068756 & 1.000000 & & \\
\hline NIMY & 0.060425 & 0.343921 & -0.212983 & -0.269582 & 0.005611 & 1.000000 & \\
\hline HHI & -0.040111 & -0.041812 & 0.001500 & 0.011224 & -0.128690 & 0.065455 & 1.000000 \\
\hline
\end{tabular}

Table 3. Panel Unit Root Test Results

\begin{tabular}{|c|c|c|c|c|c|}
\hline Methods & LLC $t^{*}$ & Breitung t-stat & IPS W-stat & ADF-Fisher $\chi^{2}$ & PP-Fisher $\chi^{2}$ \\
\hline \multicolumn{6}{|l|}{ Level } \\
\hline $\ln (\mathrm{ROA})$ & $-7.14(0.00)$ & $2.75(0.99)$ & $-0.83(0.20)$ & $104.47(0.03)$ & $159.553(0.00)$ \\
\hline $\ln (\mathrm{EQV})$ & $-11.05(0.00)$ & $1.35(0.91)$ & $-0.07(0.46)$ & $84.77(0.33)$ & $60.07(0.80)$ \\
\hline $\ln (\mathrm{LIQ})$ & $-12.66(0.00)$ & $0.55(0.71)$ & $-3.00(0.00)$ & $146.413(0.00)$ & $72.62(0.70)$ \\
\hline $\ln ($ EEFFR $)$ & $-318.60(0.00)$ & $1.54(0.9)$ & $-30.88(0.00)$ & $135.88(0.00)$ & $182.10(0.00)$ \\
\hline $\ln (\mathrm{MS})$ & $-18.47(0.00)$ & $3.55(0.99)$ & $-0.23(0.40)$ & $69.42(0.79)$ & $48.63(0.99)$ \\
\hline $\ln (\mathrm{CRIS} 1)$ & $-6.97(0.00)$ & $2.67(0.99)$ & $-0.11(0.45)$ & $97.19(0.09)$ & $130.25(0.00)$ \\
\hline $\ln ($ NIMY) & $-17.30(0.00)$ & $-2.31(0.01)$ & $-3.74(0.00)$ & $137.01(0.00)$ & $123.76(0.00)$ \\
\hline $\ln (\mathrm{HHI})$ & $-30.02(0.00)$ & $-4.70(0.00)$ & $-18.63(0.00)$ & $406.56(0.00)$ & $69.52(0.79)$ \\
\hline \multicolumn{6}{|l|}{ First Diff. } \\
\hline$\Delta \ln (\mathrm{ROA})$ & $-12.92(0.00)$ & $-0.92(0.17)$ & $-4.34(0.00)$ & $175.579(0.00)$ & $300.696(0.00)$ \\
\hline$\Delta \ln (\mathrm{EQV})$ & $-15.54(0.00)$ & $-3.31(0.00)$ & $-3.24(0.00)$ & $154.02(0.00)$ & $187.58(0.00)$ \\
\hline$\Delta \ln ($ EEFFR $)$ & $-1547.8(0.00)$ & $-3.32(0.00)$ & $-113.10(0.00)$ & $181.09(0.00)$ & $303.83(0.00)$ \\
\hline$\Delta \ln (\mathrm{MS})$ & $-23.3(0.00)$ & $-4.42(0.00)$ & $-7.86(0.00)$ & $230.83(0.00)$ & $312.59(0.00)$ \\
\hline$\Delta \ln (\mathrm{CRIS} 1)$ & $-24.93(0.00)$ & $-1.01(0.15)$ & $-6.75(0.00)$ & $198.31(0.00)$ & $267.93(0.00)$ \\
\hline$\Delta \ln (\mathrm{HHI})$ & $-13.88(0.00)$ & $-14.50(0.00)$ & $-4.29(0.00)$ & $125.45(0.00)$ & $125.46(0.00)$ \\
\hline Second Diff. & & & & & \\
\hline
\end{tabular}

Note: All variables are expressed in natural logarithms. Individual intercept and time trend are included in test regressions. These tests examines the null hypothesis of unit root (non-stationary) at 1 percent, 5 percent and 10 percent critical values using the Schwarz criterion for optimum lag differences. The figures in parenthesis are the p-values. The null hypothesis for the first two tests is the existence of a common unit root (non-stationary) while for the other three tests the null is the presence of individual unit root. 
Table 4. Hausman Test Results

\begin{tabular}{l|c}
\hline & Chi-Sq. Statistic \\
\hline Cross Section Random & $12.4527(0.0866)$ \\
\hline Hausman indicates the Hausman (1978) specification test for correlated random effects. This test examines the null hypothesis of no \\
misspecification against the alternative of specification at 5 percent critical value. The figures in parenthesis are the p-values.
\end{tabular}

Table 5. Panel Estimated Generalized Least Square (PEGLS) Regression

\begin{tabular}{l|ccc}
\hline Independent Variables & \multicolumn{3}{|c}{ Profitability (ROA) } \\
\hline Capitalization (EQV) & $-0.070^{* * *}(-3.60)$ & $-0.070^{* * *}(-3.49)$ & $-0.06^{* * *}(-3.29)$ \\
Liquidity Risk (LIQ) & $-0.021^{*}(-1.95)$ & $-0.021^{*}(-1.88)$ & $-0.020^{*}(-1.70)$ \\
Efficiency (EEFFR) & $-0.001 * * *(-6.65)$ & $-0.001 * * *(-6.64)$ & $-0.001 * * *(-6.42)$ \\
Credit Risk (CRIS1) & $-0.914 * * *(-7.63)$ & $-0.914 * * *(-7.37)$ & $-0.907 * * *(-7.09)$ \\
Net Interest Margin (NIMY) & $0.009(0.14)$ & $0.008(0.14)$ & $0.004(0.064)$ \\
Market Share (MS) & & $0.001(0.023)$ & $0.005(0.075)$ \\
Concentration Ratio (HHI) & & & $-0.017(-0.72)$ \\
Intercept & 0.0002 & 0.0002 & 0.0000 \\
\hline Observations & 420 & 420 & 420 \\
R-Squared & 0.243 & 0.243 & 0.244 \\
S.E. of regression & 0.010 & 0.010 & 0.010 \\
F. Statistic & 26.61 & 22.12 & 19.02 \\
Prob (F. Statistic) & 0.000 & 0.000 & 0.000 \\
\hline
\end{tabular}

All variables are expressed in natural logarithms. ${ }^{* * *}$ Significant at 1 percent level or $0.01 ; * *$ Significant at 5 percent level or 0.05 ;

*Significant at 10 percent level or 0.1 . The figures are in parenthesis are values of t-statistics. Three regressions are estimated to control the effects of market share and concentration variables.

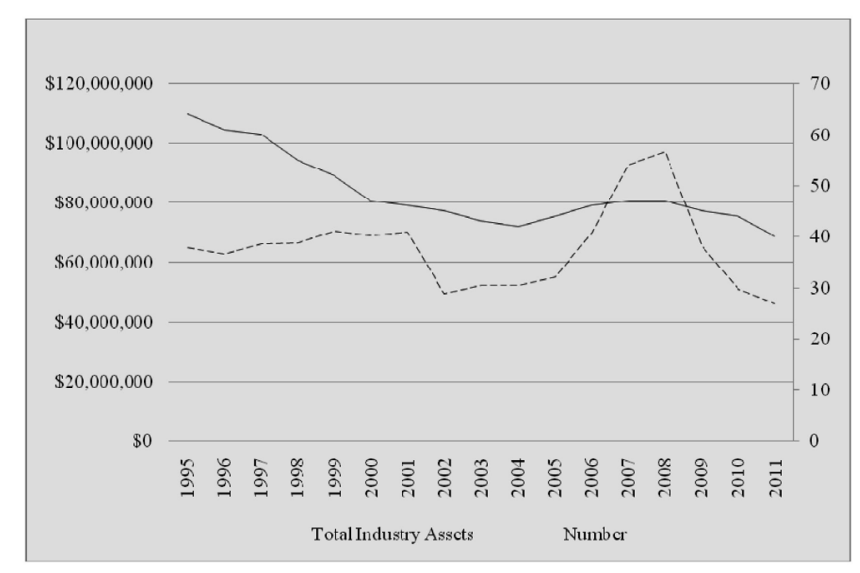

Figure 1. Consolidation in New York State S\&L Industry

Source: Authors' own calculation. FDIC Institution Directory 


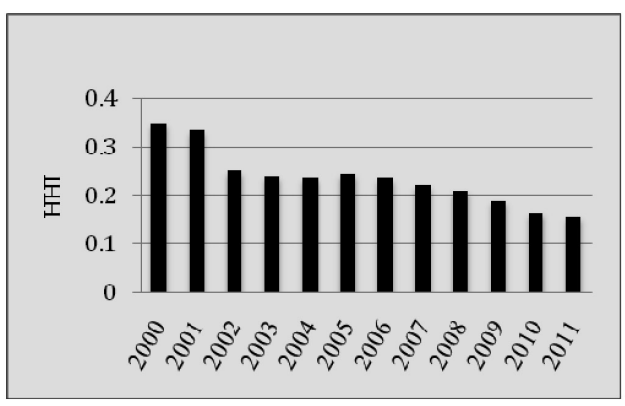

Figure 2. Market Concentration

Source: Authors' own calculation. FDIC Institution Directory

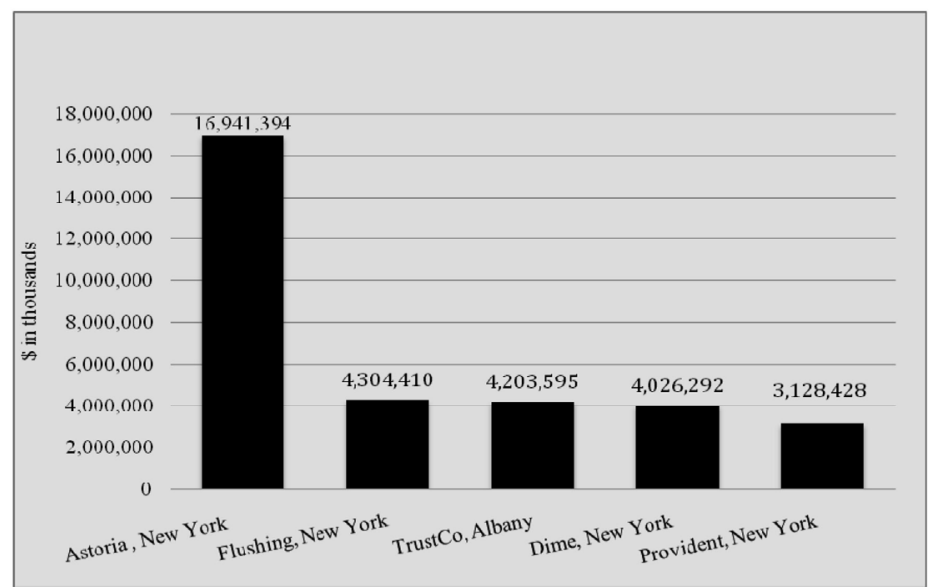

Figure 3. Largest S\&Ls, Total Assets (September 31, 2011)

Source: Authors' own calculation. FDIC Institution Directory 